\title{
Olaus Magnus, Cervantes, and a World of Marvels
}

Ted L. L. Bergman

W

Hen Cervantes scholars CiTe geographic and proto-anthropological sources for Los trabajos de Persiles y Sigismunda, they often mention Olaus Magnus and his Historia de Gentibus Septentrionalibus (A Description of the Northern Peoples) from

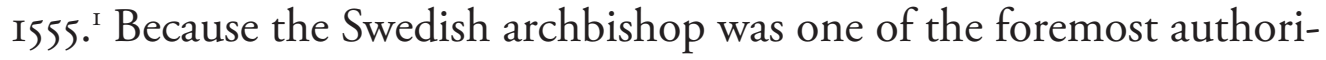
ties on the subject during Cervantes's time, it is easy to see why he continues to be repeatedly cited by modern scholars. As an avid reader of many distinct genres, Cervantes gleefully mixed sources together in his literary creations, and modern references to Olaus Magnus are mostly used to signal the blending of perceived fact with more fantastic elements that beggar belief. Cervantistas often imply that the archbishop's accounts are employed to draw a fictional setting out of the realm of pure fantasy. In their references to the source, the Spanish author makes his move towards verisimilitude by replacing classical references whose veracity have been questioned over the centuries. In this way, Cervantes places the septentrión into a more believable space that will not run afoul of his readers' potential fact-checking habits, which were driven by a steady stream of firsthand accounts and were the product of the burgeoning age of exploration.

While it is reasonable for us to treat Olaus Magnus mostly as a storehouse of facts, doing so has the potential to diminish the Swede's role as a literary influence and likewise play down the possibility that Cervantes appreciated both fantasy and realism in the same source ma-

I I am grateful to Isabel Lozano Renieblas and Claudia Rossignoli for their feedback during the preparation of this article. 
terial. Assuming that Cervantes did read A Description of the Northern Peoples in some form, and because Olaus Magnus's work contains so much marvel and magic, so many monsters and superhuman heroes, Cervantes must have detected some similarity with his beloved books of chivalry, albeit with a exotic northern twist. This study aims to demonstrate the value of including Olaus Magnus in discussions about the literary influences underlying Los trabajos de Persiles y Sigismunda. The aim here is not to trace instances in which a Swedish source supersedes its Mediterranean counterparts, but rather argue a more general point while laying the foundation for future study: a humanist author from the North is no less likely than his Southern colleagues to be a wellspring of marvelous narrative writing and romance. These aspects must be reckoned with when we cite Olaus Magnus as an inspiration, among many, for Cervantes's novel. It essential that we avoid isolating the archbishop within the generic confines of travel writing and miscellanies, lest we minimize his penchant for the marvelous, the very thing that both authors associate so heavily with the septentrion and which forms such a strong link between them.

Olaus Magnus (in Swedish, Olof Månsson) was a Catholic priest who, with the advent of the Reformation, was exiled from Sweden with his brother Johannes and eventually found refuge in Italy, spending most of his time between Rome and Venice. After his brother's death in 1544 , Olaus was named archbishop of Uppsala while in exile, and he never returned to his now permanently Protestant homeland. Through their writings, both brothers became known as chief authorities on the history, geography, and ethnography of any country north of Denmark that was not England, Ireland, or Russia. Olaus's I555 A Description of the Northern Peoples is really a commentary on his Carta Marina, a large wall map that was first printed as a woodcut sixteen years earlier in 1539. As Leena Miekkavaara explains, "With his map, Olaus Magnus wanted to rectify the faulty representation of the earlier-especially the widespread Ptolemaic_-maps, and he also wanted to show the Catholic Church the extent of the area which had been lost to Lutheranism. But, above all, he wanted to describe his dear native country as accurately and impressively as possible" (5). The original 
woodcut of the map (with only two known surviving copies) also exists in a copperplate edition from 1572 that is equally detailed, although smaller in size (Miekkavaara 4).

The content of the Carta Marina is an integral part of A Description of the Northern Peoples because the later work contains dozens of woodcuts that duplicate images from the map. While the original Carta Marina only appears in simplified form in some editions of later books, much of the full-sized map's visual content would be easily available to anybody looking at the chapter headings of the first Latin edition of A Description of the Northern Peoples from I555, as well as a number of subsequent translations. Olaus Magnus also wrote an annotated legend for the Carta Marina, a sixteen-page Italian booklet titled Opera breve, and a preliminary outline for the 815-page Latin book that was to follow. Olaus Magnus died in 1557, only two years after the publication of his written masterpiece. By I617, the year of publication for Cervantes's Los trabajos de Persiles y Sigismunda, there were at least eleven different printed versions of $A$ Description of the Northern Peoples produced throughout Europe (Ahlenius I26-33).

Olaus Magnus was certainly not the only source that Cervantes used for describing the northern reaches of the globe, but the former archbishop of Uppsala was one among a select group of true authorities, and a rare example of a widely published writer with personal experience of the region. As Isabel Lozano Renieblas has written,

Baste echar un vistazo a cualquier atlas de la época para comprobar que los nombres de Olao Magno, Zeno, Ziegler o Bohemo (Támara en la traducción española) se citan constantemente. Eran las fuentes de casi toda la documentación sobre el septentrión hasta bien entrado el siglo XVII. (Cervantes y el mundo 26)

Yet Olaus Magnus stands apart, even among these experts. Ziegler had never visited Norway or Sweden, but instead relied upon information that he obtained in Rome from four Scandinavians, specifically two Norwegian archbishops, a Swedish future schoolmaster at Vadstena, and Johannes Magnus, Olaus's own brother who was writ- 
ing his own history of the Swedish homeland (Ahlenius 35-36). Like Ziegler, Johann Boemus ("Boemo" or "Támara") was "a collector, dependent upon the observations of others," and seems to have acknowledged as much himself (Hogden 293). "Zeno" refers to Nicolò Zeno, a descendant of his exact namesake, the elder who supposedly traveled far enough north to discover the island of Frisland in the late fourteenth century. As scholars have pointed out, the veracity of the elder Zeno's (and his brother Antonio's) accounts remains seriously in doubt, and so too the younger's map made from these family sources. Also, "La archiconocida carta de navegar de Nicolò el Joven es para muchos una reelaboración ingeniosa de lugares y datos que utiliza con enorme libertad e imaginación" (Alda Heikkilä 880), and in response to one scholar's claim that "Zeno's renowned map of I 548 was the prototype of Olaus' representation of Greenland in the Carta Marina," John Granlund and G. R. Crone answer that "the contrary is certainly the case" (Granlund and Crone 37). In Cervantes's own time, the most influential Spanish "collector" and appropriator of Olaus Magnus's own accounts, Antonio de Torquemada, was not alone in his opinion of the archbishop as an authority. He wrote that among his preferred sixteenth-century authorities, Olaus Magnus was "mejor que todos," despite any limitations to the Swedish archbishop's deep personal knowledge (793). Torquemada's fascination with the septentrión is quite representative of his Jardin de flores curiosas, a book based on the idea that curiosity compels us to look into the unknown. Looking to the Far North for prominent examples created both risks and rewards for the author.

La inclusión de las materias más maravillosas e increíbles de la obra de Olao Magno contribuyó sin duda al gran éxito del JFC y de las nueve reimpresiones que alcanzó. Pero este mismo contenido también provocó el desprecio del cura en Don Quixote, que tildó la obra de una de las más disparatadas de su época. (Johnston 72)

Regarding the specific subject matter, this problematic relationship between wonder and credibility did not start with Torquemada, but rath- 
er with Olaus Magnus. He was aware of the problem and addressed it throughout his Historia.

I side with many who take for granted that Olaus Magnus, whether directly or indirectly, was a source for Cervantes. The exact amount of directly transmitted information from the archbishop's maps and texts to Persiles y Sigismunda is something that can never be measured to a precise degree. This is because his influence was widespread and could have been handed down to Cervantes through any number of intermediaries (Lozano Renieblas, Cervantes y el mundo 24). The question of direct influence is further complicated when specific sections of $A$ Description of the Northern Peoples referenced by Cervantes can be found elsewhere and themselves were probably "collected" secondhand by the archbishop. Despite his residency and travels in the North, and because he was a product of his Renaissance Humanist environment, Olaus Magnus could not avoid the lure of classical authorities. Perhaps the most cited example of complicated sourcing is the case of lycanthropy which, while cited in A Description of the Northern Peoples and Persiles y Sigismunda, can be found in authors dating all the way back from Pliny, up until debates contemporary with very writing of Cervantes's novel (Lozano Renieblas, Cervantes y el mundo 27-29).

Lozano Renieblas's thoughts on how the author of Don Quixote might have learned about werewolves reminds us that the search for sources often has been based on "el supuesto de que Cervantes no sabía latín" (30). This is supported by Daniel Eisenberg's assertion that "Cervantes no demuestra conocer ningún autor clásico que no existiera en traducción," which brings us to Eisenberg's related point that Cervantes not only read books in Italian, but must have preferred the Italian originals over their Spanish translations (Eisenberg 88, 90). This leads me to support an old assertion that, in moments when he relied upon Olaus Magnus as a source, Cervantes was most likely reading from an Italian translation (Cervantes XXIII). He surely read material in Spanish as well, but when reading Torquemada as a second-hand source, Cervantes could not have ignored his fellow Spaniard's admission that the Swedish archbishop was the best among available authorities from that time period. The widespread popularity and access to 
Italian translations seem unquestionable, whether for Storia de' costumi de' popoli settentrionali (156I) or Historia delle genti et della natura delle cose settentrionali descritta (1565), if the Universal Short Title Catalogue list of remaining extant copies-forty and fifty, respectively, and mostly in Italy-is any indication. According to Karl J. M. Ahlenius, the first Italian translation is a 'word-for-word' version of the abridged Scribonius edition, and the second is a "faithful" translation of the original work from I555. Perhaps the most noticeable difference between the two is that the later one "has, with very few and insignificant changes, the same figures in the [original Latin] I555 edition," while the earlier abridged translation contains no images at all (Ahlenius I27I28). When considering which edition Cervantes may have consulted, we should not underestimate the attractiveness of an illustrated copy of $A$ Description of the Northern Peoples. For those who desired to read about such strange and far-away lands, and also see illustrations with their own eyes, distance was no obstacle in obtaining the book by trade route. On the contrary, it is quite possible that greater distances created greater interest in reading it, as was the case of a Latin edition shipped in I608 to a certain doctor Antonio de Vargas of Lima in I608 (Rueda Ramírez 5I). And it was not only the Latin version that received geographically wide distribution.

Es así que en algún momento, el arzobispo de Uppsala, Olaus Magnus, habitante apasionado de la ciudad eterna, pudo sacar a la luz en Roma su obra Historia de gentibus septentrionalibus, en I555, dos ańos antes de morir; sin duda no sospecharía que esa misma edición de su obra pormenorizada sobre las culturas escandinavas y más nórdicas de Europa llegaría a la biblioteca del Colegio de Santa Cruz de Tlatelolco para ser leída por élites indígenas, y que una copia de la edición de 1565 , a expensas de los herederos de Luc'Antonio Iunta, también estaría disponible en la biblioteca del Colegio de San Francisco de México. (Vallejo I5I-I52). ${ }^{2}$

2 "Iunta" in the citation above refers to the Giunti printing family. The patriarch of the Giunti, Luc'Antonio, was very well connected in the world of printing and distribution in Spain in the first half of the sixteenth century, and his descendants would continue the fam- 
Eisenberg has suggested that Cervantes could have read Italian books while captive in Algiers; and the prospect of the author of Persiles $y$ Sigismunda reading the archbishop of Sweden's book in translation in North Africa does not seem any less likely than the proven cases of "élites indigenas" in Mexico or doctors in Peru, reading it in Latin. Whether he read it in Spain, Italy, or North Africa, for the purpose of this study, I will assume that Cervantes was familiar with the 1565 illustrated Historia delle genti et della natura delle cose settentrionali descritta, leaving for a later study the intriguing possibility that he may have stumbled across an unpublished Spanish translation. To my knowledge, no one has yet suggested that Cervantes read Olaus Magnus in Spanish, however there are at least two known manuscript translations written near the turn of the seventeenth century. One received royal permission to be printed in 159I, and its unknown whereabouts are all the more vexing because the translator was Don Diego López de Zúñiga (Rojo Vega, "Manuscritos y problemas de edición" I55). This nobleman was a relative of the Duke of Béjar, and it was to the duke that Cervantes dedicated the first part of his novel (Rojo Vega, "Sobre los duques" II). Until the manuscript is found, we are left with only this tenuous and tantalizing connection between Spanish and Swedish authors.

Much more can be said about the other manuscript, which is available for consultation at the Fundación Lázaro Galdiano in Madrid. I can confirm that it is a faithful translation of the Scribonius edition from Antwerp in 1562 and contains hand-drawn copies of the engravings from that edition as well. The work in Spanish is dedicated to "Su Excelencia don Alonso Pérez de Guzmán el Bueno, tercero de este

ily's strong presence in the book market there (Mano González 45). Unfortunately, surviving bookshop inventories from Spain at that time are rare, and a 1556 list from Giovanni di Giunta (known in Spain as "Juan de Junta") contains very few books in Italian, compared to the hundreds in Latin and Spanish. For this reason, it is difficult to say whether Giunta or his successors had the 1565 Venice edition in stock by the time of its printing (Pettas 9). Leaving aside the question of their immediate availability in Spanish bookshops, we do know that the books were making their way to personal libraries in Spain in parallel to their circulation throughout the empire (Cátedra 387). This proliferation means that Cervantes must have had access to an Italian edition regardless of where he was traveling. 
nombre, Duque de Medina Sidonia" (3). The ownership somewhat reduces the chance of Cervantes accessing this particular version because he wrote a scathing satire of the Duke, mercilessly ridiculing him for arriving too late in defense of Cadiz when it was sacked in 1596 (Mata Induráin 147). We know that the translation was finished after that historical event since Philip III, who started his rule in 1598 , is listed as the latest "gothic" king of Spain by the translator, along with a note that this king "reina hoy día." After this note, others writing in another hand have added the names of three more kings: Philip IV, Charles II, and Philip V (Olaus Magnus, Historia de las gentes septentrionales I764). The translator Lorenzo de San Pedro is better known today for another manuscript written in 1579 titled Diálogo llamado Filipino donde se trata del derecho que la Magestad del rey don Felipe Nuestro Señor tiene al reino de Portugal. In 1568 , he was a bachiller writing exequias on the death of Queen Isabelle of Valois (Bouza 75n), and by 1570's he had become gobernador in the town of Tocina, located about 40 kilometers to the northeast of Seville (Carmona Domínguez 80). In his dedication, San Pedro outdoes Torquemada in praising Olaus Magnus as an authority and puts him above others, including Saxo Grammaticus, for a simple reason: "este doctísimo prelado como testigo de vista, discurre con tanta erudición y elegancia [...] que es digno que en todas las partes del mundo sea leído, y muy estimado" (IO). The full story of Olaus Magnus's reception in Spain remains to be written, but the two manuscript translations cited above represent substantial efforts to bring A Description of the Northern Peoples to a wider Spanish audience during Cervantes's time. And it is possible that he was aware of these efforts, much in the same way that Lorenzo de San Pedro wrote: "Y ya que nuestra Espańa, como descubridora de casi toda la redondez de la tierra en su idioma Castellano tiene escrito todo lo que toca a las Indias oriental y occidental. También es justo que tenga lo mesmo de estos países [septentrionales]" (Io).

In Michael Armstrong-Roche's recent book Cervantes' Epic Novel: Empire, Religion, and the Dream Life of Heroes in Persiles, the author explains in his notes that Olaus Magnus is-along with others mentioned in this study - a source of "geographic details," and he appears 
to cite Antonio de Torquemada as a contrasting figure who places these details in an "unusual conceptual framework" that heightens their marvelous nature $(\mathrm{n} 3 \mathrm{I} 7,22)$. In Cervantes y la humanización de la caballería: Los trabajos de Persiles y Sigismunda, Arturo Berenguer Carisomo tellingly places Olaus Magnus in chapter VII titled "El viaje-Lo geográfico-físico," and not in "Capítulo V: Creación y fuentes de la novela." Like many other students of the novel, Berenguer treats the Swede as a source of facts and analysis that are strictly scientific, including a perspective from the early-modern social sciences. This treatment is on display when Berenguer affirms that, "el genial complutense [tenía] sobrados elementos de juicio en la historia y escritos de sus contemporáneos, sin necesidad de Olao Magno, para trazar este episodio político accidental de un reino con gobierno electivo" (190). When he writes about Cervantes's use of the marvelous, specifically "espanto" and "maravilla," Berenguer describes them as "dos efectos que el novelista se propuso al narrar las aventuras del libro" (26I).

Similar to Armstrong-Roche's implications cited above, for Berenguer there is little indication that these effects may be inspired by Olaus Magnus himself. This lack of attribution of the marvelous to A Description of the Northern Peoples seems strange if we consider what specialists on the book have to say. According to Miekkavaara, "Olaus Magnus told, in both the Italian and German commentaries 'that he wanted to give a description about the marvelous things, both on land and at sea, in the old Gothic realm and the other cold northern countries beyond the north sea" (paragraph 13 ). Indeed, his 1565 translation tells us that "Et accioche le cose Aquilonari, che in gran parte sono maravigliose, e che in questo volume si contengono, con alcuni chiari argumenti si manifestino, \& esplichino, voglio che hora narriamo alcune utilità di questo libro, le quali tra molte altre cose ne gli humani avvenimenti piu spesso possono essere necessarie" (Prefazione). It is almost as though the author fears that the "utilită" aspect of his book will be overshadowed by the "maravigliosa" nature of the examples he cites. For this reason, "alcuni chiari argumenti" encourage the reader to extract useful advice, and not simply fixate on what is marvelous and jaw-dropping. On the last page of his "Prefazione," he writes of 
things "le quali se bene in prima fronte pareranno incredibili, nondimeno essendo bene esaminate, dichiarano molti segreti di natura, e si vede, che non solo fanno fede, ma ancora eccitano maraviglia." As the Swede refers to things that "in prima fronte pareranno incredibili," the very structure of his book (to use Armstrong-Roche's terms) cannot be too far from that of Torquemada's, and by extension not too far from Cervantes's, in terms of marvel and wonder.

For Christine Marguet, Torquemada and Olaus Magnus are equivalent as sources of "informations documentées," referring to the case of skiing, and "faits fabuleux" (sea monsters and spontaneously generated barnacle birds) that a Byzantine romance writer mixes together in order to maintain a requisite amount of verisimilitude and thus not alienate readers.

Il s'agit donc d'informations documentées, que le romancier insère dans la fiction, et non d' "inventions». Il est curieux d'observer que l'auteur met un soin particulier à ne pas «inventer», alors qu'il s'agit d'horizons lointains et que la suspicion du lecteur, si tant est qu'il faille le soupçonner d'être suspicieux en matière de vraisemblance, se trouve en suspens. (Marguet 248)

Anticipating Cervantes, Olaus Magnus seems aware that he is mixing the marvelous, which stretches credulity, with information that is more readily accepted by the reader. His heading on barnacles reads "De la maravigliosa generazione de la Anatre, in Scozia," although this specific phenomenon is only covered in the last two sentences of the chapter, which is mostly dedicated to the feeding, migration, and nesting habits of the aforementioned "duck." The "maravigliosa generazione" is paradoxically the main attraction and an afterthought of the chapter, which perfunctorily concludes, "In oltre, un'altro [sic] scrittore de' Gothi, il quale con piu diligenza ha trattato le historie, dice che ne le Orchade d'un certo frutto d'un'albero [sic], che cade nel mare, si generano le Anatre" (Historia de genti settentrionali 232v).

The translator of this edition is unknown (Ahlenius I28), but he has changed the cited expert on barnacles from "Scotorum scriptor," 
in the original Latin, into "un'altro scrittore de Gothi," making him Swedish and hinting that the informed party may be an acquaintance of Olaus Magnus. This brings the cited written source farther away from the physical location of the barnacles while the passage's verisimilitude is maintained by suggesting that the author of $A$ Description of the Northern Peoples was able to interrogate the source of the information first-hand. Despite the writer's implied proximity-by reading or personal interaction - to his informant, the phenomenon of birds hatching from trees is not held as any less marvelous, and in spite of efforts by both author and translator to eschew distant Classical sources in favor of closer contemporary ones. I agree with Lozano Renieblas that in the case of the barnacles, "ni Torquemada ni Olao Magno explican las pistas dispersas que hacen del autor del Persiles un hijo de su tiempo" ("Sobre el barnaclas del Persiles" I50). While we cannot measure exactly how much information Cervantes drew directly from each specific source, he was doing more than assimilating cold hard facts; he was absorbing a sense of the marvelous that was indicated as such in the sources themselves. When Cervantes's narrator mentions "pájaros que se crían en aquellas partes, de tan extraña manera, que, por ser rara y peregrina, me obliga a que aquí la cuente," the sense of marvel is likely no embellishment but rather the conservation of an attitude that was inherent in a source text (Persiles 87).

According to Marguet, Byzantine romances contain "fait fabuleux" and "informations documentées" "sur le meme plan," and these are held in tension with one another. For Olaus Magnus, the emphasis on the marvelous meant that the tension between the factual and fabulous did not matter much. We must refer to the exact term "marvelous" because the use of the word "fabuloso" (to cite Marguet's "fait fabuleux") in the 1565 edition is exceedingly rare and can be synonymous with the term "falsa" (as with judicial astrology cited on fol. 227v), creating a clear separation between fact and fiction. To see how the tension cited above is often absent in Olaus Magnus, let us look at skis (or possibly ice skates), which Marguet cites as one of the "informations documentées" (248). Lozano Renieblas argues that Cervantes connects the less believable oral tradition of medieval monsters to more believ- 
able Renaissance first-hand descriptions of, "hombres que se deslizaban sobre un solo pie, convirtiendo así a unos vulgares patinadores en los fabulosos imantópodos" (Cervantes y el mundo I6I). This would seem to indicate some separation, if not outright tension, between what is classically dubious ("fabulosos") and mundanely believable ("vulgares"). But if we read one of Olaus Magnus's own accounts, from a Northern perspective these "patinadores" are not as "vulgares" as one might expect. In book four, chapter three, when returning to the subject of "la ferocità de gli huomini salvatichi," the archbishop explains "Perche con maravigliosa destrezza, volgendosi per ogni verso (si come si è detto nel I. libro, de li Scricfinnii) \& aggirandosi d'ogn'intorno, sanno schifare, e fuggire ogni impeto, che gli venisse incontro" (53v). Here he is repeating the term "maravigliosa destrezza" as applied to the Scricfinnii in book one, chapter four (3r), those who "con maravigliosa prestezza, usano certi legni, lisci, e piani, piegati, e ritorti da la parte davanti a guisa di archi” (2v). Taken solely as crafted objects, the skis or skates are perhaps not themselves marvelous, but the Scricfinnii's ability to use them is, and Olaus Magnus seems quite aware that his authoritative report has the ability to astound his readers without much risk of eliciting disbelief.

An exact count of the words "maraviglia," "maraviglioso," or related terms is difficult to make without a precise digital edition of the 1565 Italian translation; but a preliminary attempt of a scanned copy reveals about 200 occurrences. This means that an explicit reference to marvel appears, on average, every three pages or so in that edition. This number and average far exceed that of any mention of "maravilla" or "admiración" combined in Persiles y Sigismunda. From a lexicographical and statistical perspective, we may say that Cervantes includes less marvel per page than a source seen by many modern scholars as a scientificethnographic sourcebook. And yet Olaus Magnus's book, with its high concentration of the marvelous, contains an inversely proportional lack of concern about verisimilitude as a topic compared to Cervantes's novel. The archbishop is not gripped, as E. C. Riley wrote of Cervantes and Torquato Tasso, by an "obsessive concern with verisimilitude and the marvellous" (8). This is because there is never the suggestion that 
A Description of the Northern Peoples or the stories within it should be treated as works of imaginative literature. In this way, Olaus Magnus could rest assured that despite any doubts that his readers may have, they would never come close to echoing Giovanni Battista Pigna's complaint about the romance genre from 1554 :

Le Spagnole Romanzerie quasi tutte di uanità son piene: stando elle solo in su i miracoli: \& con li spirit ò dell'una sorte ò dell'altra facendo sempre naascere cose dal naturale lontane, $\&$ dal diletto, che per leggitime maraviglie suol nascere. (Forcione 27)

But production and purpose are one thing, and reception is another. Despite any condemnation of romance that may have loomed over Olaus Magnus and his contemporaries, they had no control over how their works were read and picked apart, or how pieces of them were adapted to fit a model that they were urged to avoid. Romance and the revival of classical tragedy as genres must have been far from the archbishop's mind when he wrote his masterpiece, but this did not prevent Tasso from drawing heavily on A Description of the Northern Peoples when he combined both in Il Re Torrismondo. As Anthony Oldcorn writes in his introduction to a bilingual edition of the tragedy, in its first iteration, "The preposterous plot claims to be based on history, and the ever-scrupulous Tasso will wind up combing Olaus Magnus's recently published history of Scandinavia for documentary plot-hooks, local color, and customs" (Tasso, King Torrismondo I4). Beyond being "absurd," the plot lacks "any credible transcendental superstructure [or] any sacred or religious apparatus."

It is hard to take seriously the oracle or Macbeth-like witch's prophecy (which we do not learn about in any case until Act IV of five acts) that is supposed to have set the foreplot in motion. It belongs, like so many of the background details, more to the world of pastoral romance and melodrama than that of tragedy, and raises questions of verisimilitude that are quite impossible to swallow. (23-24) 
Can all of these "questions of verisimilitude" be completely attributed to Tasso? Cannot the seed of romance be found in Olaus Magnus, with all his emphasis on marvels, despite the Swedish archbishop's best intentions to remove any doubt from his readers' minds? Among the "documentary plot-hooks, local color, and customs" cited by Oldcorn, why not include a heavy concentration of the marvelous?

The prophecy that Oldcorn cites is based on an example from A Description of the Northern Peoples, and the editor Vercingetorige Martignone reminds us that for the lines "Il parlar la destò d'accorte ninfe / Ch'altrui soglion predir gli eterni fati,' di ninfe nordiche dotate di tal facoltà profetiche discorre Olao Magno, Historia, III Io" (Il Rey Torrismondo 175n). Olaus Magnus, himself citing Saxo Grammaticus, provides this romance-tinged information through the character Rosamunda, from whom we learn,

Quel palagio, quel antro, e quelle ninfe, E quelle antiche usanze, e l'arti maghe, Eran sospette a la pietosa madre, A cui mostrata fui, volgendo il sole Già de la vita mia il secondo corso, Pur come figlia sua, né mi conobbe' E'l re fece l'inganno, e 'l tenne occulto. (I76)

In the same chapter that inspired Tasso to write about the nymphs and their prophecies, Olaus Magnus writes of their "inganni," but not in the sense that mundane trickery underlies apparent magical ability. That these creatures can perform truly magic feats is not in question, especially if we consider the opening sentence of the chapter. "Erano oltra di questi, ne 1 terre Aquilonari alcuni tempii, consecrati a Cerere, \& a Diana, e certe chiese de la forelle fatali, fabricate senza opera humana, ma con un'incanto, e con artifizio prestigioso" (4Ir). The chapter contains a story of Høther (adversary of the Norse demi-god Balder) who, by beautifully playing a "cethera," "meritò ricevere da loro una cinta ornatissima, \& una certa fascia, la quale chi la portaua sempre haveva vittoria" (4Ir). If Oldcorn finds that Tasso's tragedy "raises questions of 
verisimilitude that are quite impossible to swallow," the Swedish source from which the Italian drew is equally guilty.

Also, were we to make accusations, it would be unfair to charge Olaus Magnus with being "unscrupulous" and negatively influencing Tasso since the archbishop's authority was heavily reinforced by his status as an eyewitness. Unintentionally, his History benefits from the neo-Aristotelian theory of epic espoused by Tasso: 'the poet should set aside the exact truth about things which learned men rightly called impossible; it was enough for him to adhere to popular opinion in such cases' (Riley I9I). Northern tales whose verisimilitude may seem "quite impossible to swallow" by modern readers are given the benefit of the doubt when told by a person like Olaus Magnus, who was close to the source. The chapter quoted above belongs to an entire libro in $A$ Description of the Northern Peoples. In the Italian translation it is titled "De la superstiziosa cultura de li Demonii, de' populi Aquilonari" but the chapter includes magic as a marvelous matter of fact more than an actual case of superstition to be avoided or condemned.

Cervantes was no doubt skeptical of many claims made by Olaus Magnus, especially those regarding magic and witchcraft, and modifies the narrative frames in his novel accordingly by placing distance between the source of the information and the receiver (Riley I9I). The argument being made in this study is precisely that the Spaniard saw Olaus Magnus as more than a source of facts, and even that facts themselves may not have been what Cervantes was after. Given his ironic nature, it is even possible that he chuckled to himself as he read A Description of the Northern Peoples. In writing Don Quixote, "If the overt target of his satire is the romances of chivalry, it can hardly be the principal one. His chief butt was man's gullibility-gullibility about alleged historical facts" (Wardropper Io). The same satire could be said to exist with a lighter touch in Los trabajos de Persiles y Sigismunda but not as a means to take down an entire literary genre, whether it be history or romance. While Don Quixote is the "ultimate meta-romance" (Dudley 55) and his last novel is a "Christian romance," "Cervantes worked within the genre, exposing its limitations not through ridicule, but by playing with and twisting its most entrenched assump- 
tions" (Sacchetti 72). Olaus Magnus's history, a text rife with elements of romance and unremitting references to the marvelous, provided Cervantes with a felicitous confluence of material that could be plundered and manipulated more like one of his favorite works of literary invention than a bland sourcebook for facts on the far North. While Cervantes did not necessarily prefer the Description as a source above others in all circumstances, its inadvertent genre-mixing would have held particular appeal to him. In the earnest Olaus Magnus, the ironic Cervantes found an unwitting ally and what the Spaniard may have found ridiculous in the Swede's writings could also remind him of his fondness for romance.

A critical point of view that defines Olaus Magnus as a source of marvel can aid us in developing novel interpretations of Persiles y Sigismunda, keeping in mind that Cervantes did not always copy his sources outright. In the novel there are no giants of the sort in Renaissance Romances like Felixmarte de Hircania, or in Byzantine romances like the giant at the end of Heliodorus's own Aethiopica. On the other hand, we do find something that echoes those sources, and is also a feature of giants in $A$ Description of the Northern Peoples, namely feats of superhuman strength. The textual origin of such feats can be classical, as in the Aethiopica, in which the hero Theagenes (the possible inspiration for Periandro) does manage to bring a bull to its knees, with the help of a horse, and also defeats a giant in a wrestling match. While a giant-wrestling and ancient rodeo are not exactly the same activities as Periandro's athletic feats on the island of King Policarpo in book one, chapter 22, there are similarities. Cervantes's protagonist wins a footrace, fencing contest, and first prize for marksmanship. He also defeats six men (apparently at once) in a wrestling match, and then throws a heavy iron bar so far that it lands out of the bounds of the contest and into the ocean. While Periandro is not a giant, or a monster, his actions are superhuman, even "monstrous." We read that "esta mostruosidad, notada de sus contrarios, les desmayó los bríos, y no osaron probarse en la contienda" (II9).

If Cervantes did read the exact accounts of Norse heroes in Olaus Magnus, it is quite possible that he took Heliodorus's model of the 
athletic hero and combined it with the $A$ Description of the Northern People's countless fighters, not the least of which is the giant-hero Starkað. We may also consider how in Persiles y Sigismunda, the bárbara interpreter Transila is described as "menos tierna, más animosa," and walks "con varonil brio" while the other civilized women in the group must ride on the shoulders of the men (38). After a detailed and thorough investigation of many possible written sources for the character Transila, especially in the context of the character's backstory relating ius primae noctis, Lozano Renieblas concludes,

Es muy probable que Cervantes tomase la anécdota de Támara-o de cualquier otro, esto poco importa-, pero lo realmente relevante es el vínculo que establece entre historia y espacio al que se la atribuye. No estamos ante un listado de costumbres, sino ante un esfuerzo sin precedentes por ensamblar espacio y tiempo o, lo que es lo mismo, historia. No se describe cómo son los habitantes de las inmediaciones de Hibernia, sino que el autor construye una historia y unos personajes con un conjunto de ritos y costumbres que definen su carácter y están en consonancia con las de las inmediaciones del lugar de donde dicen ser originarios. (Cervantes y el mundo I42)

I agree that focusing too much on the "listado de costumbres" makes us lose sight of Cervantes's ability to weave a story together. At the same time, compelling storytelling requires compelling characters. For Lozano Renieblas, Cervantes is imprecisely referring to the rough environment in and around Hibernia as the basis for "el carácter impetuoso, resuelto y decidido de Transila" (I42). While this makes perfect sense, cannot the description of Transila as "menos tierna, más animosa," and "con varonil brío," along with her refusal to be carried, also refer to her physical strength as a "bárbara" character? This presentation of unusual female strength in a woman could be part of Cervantes's clever narrative technique (Múñoz Sánchez 260), or to evoke classical antecedents (Bearden calls Transila "Amazon-like" [219]); but the character construction can be equally influenced by Olaus Magnus's 
marvelous descriptions. In chapter two of the fifth "libro," "de giganti," to which we have referred earlier, the author cites Starkað and other heroes in extremely brief fashion, and quickly explains that he wishes to name "alcuni altri huomini, stati a li nostri tempi" from "Svezia" and "Gothia," "li quali erano dotati di tanta fortezza, che ciascuno di loro portava sopra le spalle sue un cavallo, o un gran bove, anzi un vaso di ferro, di seicento, ottocento, e mille libre, per spazio di molti stadii (il qual peso ancora, alcune fanciulle possono alzare)" (57v).

While not from Hibernia, these examples of superhumanly strong "fanciulle" could have inspired Cervantes in his creation of bárbaras as much as any other source. As Diana de Armas Wilson writes of "Sulpicia, the pirate woman," this character's story "was undoubtedly inspired by Olao Magno's book of Northern customs, in which he recalls various women warriors, among whom was one Alvida" (I86). She is described in chapter 27 as "vergine illustrissima, e nobilissima" who "incominciò a esercitare un'atrocissima Piratica, e raccolse à se per compagne de la guerra, che fare intendeva, molte fanciulle, e giovane, che havevano il medesimo desiderio" (7or). Along with being the Alvild who gave her name to the heroine from Tasso's tragedy, in Olaus Magnus she is a figure pursued at sea by Alf, himself described in chapter I8 as a "difensore de la pudicizia" who defeated two guardian serpents in his first attempt to wed the female warrior. Alf's narrative is nestled among that of Frotholde, Haroldo, and other "pugile" of the romance-tinged stories similar to that of Høther previously cited. From contemporary women lifting thousand-pound vessels to piratewarrior-maidens guarded by serpents, Cervantes had plenty of authentic Scandinavian examples from which to choose in the construction of his strong female characters.

But why look North instead of South for these examples? The balance for Cervantes could have been tipped by what he read after finding "undoubtable inspiration" for the character of Sulpicia in chapter 27. Chapter 28 describes numerous authorities who ascribe the origin of the Amazons to Gothia. In chapter 30, he further defends the North as a prime source of warrior women, worrying that some readers may cross the line from wonder into incredulity. 
Non deve arreccarne maraviglia, o causarci incredulità, sentendo noi dire, che le donne Gothiche già efercitarono grandissime guerre: poi che esse sin da le fascie, si nutricavano, avvezzavano in costumi severi, e ne la disciplina militare ... Acchioche da la insolenza dè Pugili, conservassero intatta la lor pudicizia, li quali non errano ritratti da l'horrore de lo stupro." (7Ir-v)

This is not to say that Cervantes merely took the archbishop at this word or was swayed by old-fashioned auctoritas, only that familiarity with the Swede made it easy for the Spaniard to put a Northern twist on the traditional Amazonian stereotype. We should not feel obligated to limit "Cervantes's playfully irreverent way with the literary tradition in this novel" (Armstrong-Roche 13I) to his use of classical, or Italian, or Spanish sources. The novelist's ironic point of view, tempered with his sympathy for fellow writers seduced by romance, allow him to gently ridicule Olaus Magnus while simultaneously using him for literary inspiration. Sulpicia herself seems to echo the words of the archbishop when she explains to Periandro:

Bien creo, ¡oh soldados!, que os pone más admiración que miedo este pequeño escuadrón de mujeres que a la vista se os ofrece, el cual, después de la venganza que hemos tomado de nuestros agravios, no hay cosa que pueda engendrar en nosotras temor alguno. Embestid, si venís sedientos de sangre, y derramad la nuestra quitándonos las vidas; que, como no nos quitéis las honras, las daremos por bien empleadas. (267)

Wilson points out that the male offenders in Cervantes's scenario are drunk and "the anger of endangered women could extend to all this cruelty," making it more of a slaughter than a fair fight on the field of battle (I87). Cervantes may have shared Olaus Magnus's worries about beggaring belief, but his desire to create a believably bloody result does not undercut Sulpicia's warrior woman status. Her humble explanation of "es cosa natural defender cada uno su vida" is betrayed by her splendid armor and weapons. If we are to suspend disbelief in the face 
of such an extravagant figure, then we must also accept the implication that military training is part of Sulpicia's heritage. The wonder that she provokes does not strain credulity while it remains strongly linked to the spirit of romance in Olaus Magnus that infuses so much of his Historia.

With a copy of A Description of the Northern Peoples on hand, Cervantes would not have needed to look further to find inspiration for many of his wondrous characters, especially those who were identified as Nordic in origin. And yet today, despite the availability of Olaus Magnus for study, the lure of classical sources remains strong among modern scholars. When studying the possible antecedents of Bradamiro from the Ínsula Bárbara, Miguel Alarcos writes that, while the descriptors "menospreciador," "arrogante," and "atrevido" characterize the barbarian as anti-heroic, other adjectives also feature in Bradamiro's first appearance. These are "valiente" and "principal":

están en consonancia con la caracterización heroica y, en concreto, con dos de los motivos literarios que refuerzan y acentúan el tópico del virtuosismo moral y/o espiritual, a saber: el de la virtus o "valor, coraje» y el de la «nobleza de origen, preeminencia social». Por lo tanto, nuestro Bárbaro, a pesar de su condición étnica, aparenta cumplir con los requisitos del estereotipo caballeresco[.] (270)

According to Alarcos, through an elaborate process of "reelaboración," Cervantes has twisted certain aspects and inverted others in his use of Virgil's Mecencius character from the Aeneiad as a model. The critic deems the positive "caballeresco" aspects relatively superficial, and while "Cervantes prescinde del componente criminal y truculento," a violent streak and their shared use of violence still link Mecencius and Bradamiro together (288).

All of us who trace the influences behind Persiles y Sigismunda must concede that Cervantes is in a constant mode of "reelaboración," and we will admit that rarely does a critic's preferred source line up perfectly with its referent in the novel. It is quite possible that Cervantes may have been thinking of the Aeneiad when outlining his Bradamiro, 
but then why make any attempt to extol the character's virtus, to use Alarcos's term? My explanation is that Olaus Magnus and his sources, like Saxo Grammaticus, were as inspirational as Virgil or other classical authors. Bradamiro bears as much in common with the many "pugile" named by the Swedish archbishop as he does with models from antiquity. Cervantes may not hold up Bradamiro as an exemplar like Starkad, and the barbarian's carnal appetites contrast with the nordic hero's strict diet and aversion to rich food, but Bradamiro's combined virtus and love of violence create a powerful connection between the two characters.

Chapter four of Olaus Magnus's fifth "libro" is titled "De le virtù, e valore del fortissimo Gigante Starchatero" and balances Starkað’s exemplary denouncement of gluttony with the hero's "estupenda, \&, incredíbil vírtù, e valore, assai maggiore d'ogni comune statura humana [...] Sî che si giudicava, che piu valoroso di lui ni uno si ritrovasse" (59r). This description is not too distant from that of Bradamiro, "de los más valientes y más principales de toda la isla, menospreciador de toda ley, arrogante sobre la misma arrogancia, y atrevido tanto como él mismo, porque no se halla con quién compararlo" (2I). While Scandinavian sources describe Starkað as a punisher of arrogance and not a victim of excess pride, his haughtiness is legendary when showing off his twin virtues of temperance and valor. In one battle, When asked if he would take on his opponents one at a time or in a group, he responds: "Ogni volta, che una trista schiera di cani mi abbaia, io soglio tutti insieme scacciarli, en on a uno a uno" (59v). When asked why he is carrying a bundle of charcoal on his way to dissuade a Danish king from debauchery, Starkad answers that he "volveva ridurre la stoltizia, e grossezza del Re Ingello a la perduta prudenza, \& acutezza..." (59v). $\mathrm{He}$ is not "menospreciador de toda ley," but Starkað does resort to dirty tricks in combat because winning for him is everything. When thrown off balance by a punch laid on him by Hama the Saxon, the hero chops his opponent in half with a sword instead of swinging back (59r). With good reason P. G. Foote, the editor of the English translation of $A$ Description of the Northern Peoples, called him "the hardiest, most obdurate champion of all." 
In contrast to Starkað's long reign as a fighter, Bradamiro's life is cut short in a moment that Armstrong-Roche calls reminiscent of Antinous's death in the opening of book 22 of the Odyssey (ArmstrongRoche 130). While the specific action may be drawn from a classical source, the character-types involved are quite different. Odysseus the archer bears little resemblance to the "bárbaro governador," but this gap can be explained because "in ways large and small we can detect the will to rewrite epic" (130). All the while, it seems unlikely that Cervantes "aficionado a leer aunque sean los papeles rotos de las calles" would stop short at Homer, Virgil, and Heliodorus in his rewriting process (I: 9). If reinterpreting and incorporating Virgil required a thorough "reelaboración globalizadora" (Alarcos 283), then mixing in details from Olaus Magnus seems wholly appropriate for Cervantes when he was constructing forceful and potentially violent characters.

Taking a closer look at of $A$ Description of the Northern Peoples can also make us reconsider Cervantes's use of witches and wizards in Los trabajos de Persiles y Sigismunda. The most prominent example is that of Rutilio's story in book one, chapter 8, of how he was carried through the air by a witch who later turned into a wolf. Instead of adding to the scholarship on werewolves in the novel, I cite an embedded declaration in the same narrative that, "Puedes, buen hombre, dar infinitas gracias al Cielo por haberte librado del poder destas maléficas hechiceras, de las cuales hay mucha abundancia en estas setentrionales partes" (60). Outside of the story's frame, one of Rutilio's listeners, Mauricio, dismisses the true existence of werewolves, but explains their appearance through, "la fuerza de los hechizos de los maléficos y encantadores, que los hay, nos hace ver una cosa por otra" (IOI). From this moment in the novel, the debate about men transforming into animals remains strong, but the existence of sorcerers is not severely questioned in the same manner. Olaus Magnus is often treated by modern scholars as a sort of proto-ethnographer or proto-folklorist, but in his Description, he does more than offer descriptions of customs and superstitions. He tells stories of sorcerers, just as the characters do in Persiles y Sigismunda. In the novel, there is an ebb and flow between the genres of romance 
and miscellany, or travel literature, which may sway Cervantes towards adopting one mode or another, disguising the origins of his inspiration.

One example of the author's obfuscation is the creation of Cenotia, a sorceress character who is clearly identified as a morisca from Granada and on the run from the Spanish Inquisition. As Lozano Renieblas (citing Avalle-Arce) points out, Cenotia is not the first such witch from Granada created by Cervantes (Cervantes y el mundo I45), but we may want to reconsider her role as someone who imports exotic Mediterranean magic to the North. She is not a true outsider if we interpret her as akin to "destas maléficas hechiceras, de las cuales hay mucha abundancia en estas setentrionales partes," and from this critical point of view, Cervantes's North is a place that has room for plenty of witches (Cervantes 60). This is not simply because the magic arts form a detail found on one of Olaus Magnus's "listado de costumbres," to borrow Lozano Reniebla's wording (Cervantes y el mundo I43). Instead, "el autor construye una historia y unos personajes con un conjunto de ritos y costumbres que definen su carácter y están en consonancia con las de las inmediaciones del lugar de donde dicen ser originarios" (I42). The North is a region that invites magical practice through its very geographical essence. This essence is a perfect medium through which the factual miscellany genre can be reconciled with romance through a preponderance of marvels, as much in A Description of the Northern Peoples as in Persiles y Sigismunda.

The same essence allows for the possibility that Olaus Magnus's work inspired Cervantes's novel's own hybridity in part, and also explains a possible origin for some of the seeming contradictions therein. Judith A. Whitenack writes that in Cervantes's works overall,

the world of magic and enchantment, as Américo Castro observed long ago, seems to have fascinated Cervantes, which might partially explain his attraction to the libros de caballerias. Several of his other works also contain various references to magic and the supernatural. Naturally in those days of Tridentine strictures on imaginative literature and the dangers of Inquisitional investigation to suspected practitioners of magic, an author could hardly allow the 
presence of efficacious magic in his works, and Cervantes therefore always weakens or questions its effects within his plots. (8I)

From what we have seen from Olaus Magnus's portrayals of efficacious magic, albeit extracted from a legendary past, there is no prohibition in publishing a book-in Rome no less-that eschews the obligation to "always weaken or question the effects" of magic. If Cervantes followed the model of $A$ Description of the Northern Peoples to any degree, he probably felt less pressure to qualify his tales of magic than some critics have supposed. In his article, "Magic in the Spanish Golden Age: Cervantes's Second Thoughts," Stephan Harrison writes,

Inconsistencies we have noted in the statement of the theme of freewill and in the rationalization of fantastic events themselves, and the disparity that still remains in the novel between theoretical statements on magic and the role it effectively plays in the story, should all be taken as signs that this aspect of revision was Cervantes's last work on the novel, and that he was probably unable to complete it (6I).

I would argue that the Spaniard did not see the Swedish archbishop's plentiful tales of wizards, witches, and magical giants as plagued with 'inconsistencies,' but rather as compelling storytelling in the romance tradition without the need for constant qualification. For this reason, as modern critics, I think that we should feel less obligated to demand from Cervantes any obsessive fact-checking, or doctrinal looking back over his shoulder, any more than we would demand the same of the archbishop, who does mention the diabolical origin of magic, but does little to question its overall presence and efficacy.

As much as serpents, dragons, and sea monsters represent marvels, and form an overlap between romance and Olaus Magnus's work, I have not dedicated much space to them in this study. This is because the subject has already been thoroughly investigated by Lozano Renieblas in the context of the náufrago, the only beast approaching a dragon or serpent in Persiles y Sigismunda (Cervantes y el mundo I48-52). Perhaps 
the only thing that I can add, or emphasize, is what Lozano Renieblas writes about the sea monster's appearance in Periandro's narration as evidence of the character's capacity to "fantasear" or his ability to relieve Cervantes from having to "convertir la imposibilidad de lo narrado en capacidad fabuladora' ( 152 ). Certainly, Cervantes had to contend with how a story of sea monsters might affect the verisimilitude of his overarching narrative of pilgrimage from the septentrión to Rome; but he would have received some consolation from Olaus Magnus's own assurances to the reader. In the same sentence in which he describes how the fisitere or priste can swamp ships, or at least endanger the crew, with its overwhelming water spout, the archbishop insists, 'Nè ciò è maraviglioso, perche questo Priste, secondo che testifica Vincenzio, é una fiera di tanta altezza' and can raise itself to such a height and spray so much water that it is 'come un diluvio' (fol. 263r). It is almost as though the author, perhaps like Cervantes on occasion, feels that he has sailed too far into the sea of marvels, perhaps even into the realm of romance, and must turn back if he is to maintain some balance between different genres and influences in his writing.

Such generic movement need not be accompanied by anxiety, based on either Church doctrine or classical literary precepts. In both its Latin (I555) and Italian (1565) versions, A Description of the Northern Peoples is titled a Historia, but it is the respective subtitles that really tell the whole story in terms of its likely reception from a reader like Cervantes. The Latin subtitle is: "Earumque diversis statibus, conditionibus, moribus, ritibus, superstitionibus, disciplinis, exercitiis, regimini, victu, bellis, structuris, instrumentis, ac mineris metallicis \& rebus mirabilibus, necnon universis penè animalibus in Septentrione de genitbus, eorumque natura." The Italian subtitle is much shorter and emphasizes one particular aspect: "Opera molto dilettevole per le varie \& mirabili cose, molto diverse dalle nostre, che in essa si leggono." Los trabajos de Persiles y Sigismunda is subtitled "Historia Septentrional," but is not the dry, fact-filled miscellany implied by the Latin subtitle of the 1555 edition of Olaus Magnus's Historia. The novel is, especially in its first half, much more an "opera molto dilettevole per le varie $\&$ mirabili cose, molto diverse dalle nostre." 
Much has been written on Cervantes's use of marvel and romance, and the degree to which these can interfere or reconcile with particular artistic aims, such as verisimilitude and the honoring of classical tradition. The studies will continue, and so will the debates about Cervantes's influences and motivations regarding his genre-mixing and artistic vision. While the purpose of this study has been to join such debates in a rather narrow sense, the hope here is that Olaus Magnus can now be included in a broader context as a source of literary inspiration and not just a source of marvelous information. In the prologue to his novel number 72 in his collection of Novelle, Matteo Bandello writes, "E se mai fu età ove si vedessero di mirabili e differenti cose, credo io che la nostra età sia una di quelle, nella quale molto più che in nessun'altra, cose degne di stupore, di compassione e di biasimo accadono" (665). Bandello was commenting upon the religious-political landscape of Europe, but his "age of marvels" can equally be applied to the times and places that infuse the imaginations of both Cervantes and Olaus Magnus, and bind them together through a shared sense of wonder.

\section{University of ST. Andrews tb59@st-andrews.ac.uk}

\section{Works Cited}

Ahlenius, Karl J. M. Olaus Magnus och Hans Framställning af Nordens Geografi; Studier i Geografiens Historia. Uppsala: Almqvist \& Wiksells, I895.

Alda Heikkilä, María del Carmen Díaz de. "Ultima Thule’ y el Contexto Nórdico de Los Trabajos de Persiles y Sigismunda." Volver a Cervantes: Actas del IV Congreso Internacional de la Asociación de Cervantistas: Lepanto, I-8 de octubre de 2000. Ed. Antonio Pablo Bernat. 2 vols. Palma: Universitat de les Illes Balears, 200I. 2: $875-886$.

Armstrong-Roche, Michael. Cervantes' Epic Novel: Empire, Religion and the Dream Life of Heroes in Persiles. Toronto: U of Toronto P, 2009.

Bandello, Matteo. Novelle Di Matteo Bandello. Firenze: Borghi, I832.

Berenguer Carisomo, Arturo. Cervantes y la humanización de la caballería: LOS TRABAJOS DE PERSILES Y SIGISMUNDA. Buenos Aires: Universidad del Salvador, I995.

Bouza, Fernando. Imagen y propaganda: Capitulos de historia cultural del reinado de Felipe II. Móstoles: AKAL, 1998. 
Carmona Domínguez, José María. Libro de Privilegios de la encomienda de Tocina, I242-I692. Sevilla: Diputación de Sevilla, I999.

Cátedra, Pedro M. Nobleza y lectura en tiempos de Felipe II: La biblioteca de don Alonso Osorio marqués de Astorga. Junta de Castilla y León, Consejería de Educación y Cultura: 2002.

Cervantes Saavedra, Miguel de. Persiles y Sigismunda. Ed. Rudolph Schevill and Adolfo

Bonilla. Madrid: Bernardo Rodríguez, I9I4. <http://www.cervantesvirtual.com/obra/ persiles-y-sigismunda--o/> Web.

Dudley, Edward J. The Endless Text: DON QUIXOTE and the Hermeneutics of Romance. Albany: State U of New York P, 1997.

Forcione, Alban K. Cervantes, Aristotle, and the PERSILES. Princeton: Princeton UP, I970.

Fuchs, Barbara. Romance. New York: Routledge, 2004.

Gallardo, Bartolomé José. Ensayo de una biblioteca española de libros raros y curiosos. 4 vols. Vol. 4. Madrid: Tello, I889.

Granlund, John, and G. R. Crone. "The Carta Marina of Olaus Magnus." Imago Mundi 8 (195I): 35-43. Web.

Harrison, Stephen "Magic in the Spanish Golden Age: Cervantes's Second Thoughts." Renaissance and Reformation / Renaissance et Réforme I6.I (1980): 47-64.

Hodgen, Margaret T. "Johann Boemus (fl. I500): An Early Anthropologist." American Anthropologist 55.2 (1953): 284-94. Web.

Johnston, Michael D. "La retórica del saber en el Jardín de flores curiosas de Torquemada." Journal of Hispanic Philology 3 (1978): 69-83.

Kalinke, Marianne E. Bridal-quest Romance in Medieval Iceland. Ithaca: Cornell UP, I990.

Lozano Renieblas, Isabel. Cervantes y el mundo del PERSILES. Alcalá de Henares: Centro de Estudios Cervantinos, 1998.

—. "Sobre El barnaclas del Persiles." Nueva Revista de Filología Hispánica 42.I (I994): I43-50.

Magnus, Olaus. A Description of the Northern Peoples, Rome 1555. Ed. Peter Foote and John Granlund. Trans. Peter Fisher and Humphrey Higgens. London: Hakluyt Society, 1998.

- Historia de gentibus septentrionalibus. Rome: Joannes Maria de Viottis, I555.

-. Historia de las gentes septentrionales. Trans. Lorenzo de San Pedro. 2 vols. I60I(?). Ms. Fundación Lázaro Galdiano, Madrid.

-. Historia delle genti et della natura delle cose settentrionali. Vencice: Appresso i Giunti, 1565 .

-. Opera breve. Venice: Giovanni Thomaso, I539.

- Storia del costumi dei populi settentrionali. Venice: Francesco Bindoni, I56I.

Mano González, Marta de la. Mercaderes e Impresores de Libros en la Salamanca del Siglo XVI. Salamanca: Universidad de Salamanca, I998. 
Marguet, Christine. "Voyage, aventure et poétique dans le roman byzantin." In Meunier, Philippe, and Jacques Soubeyroux. Le voyage dans le monde ibérique et ibéro-américain: Actes du XXIXE Congrès de la Société des hispanistes français, Saint-Etienne, I9-20-2I mars I999. Saint-Etienne: Publications de l'Université de St-Etienne, 1999.

Mata Induráin, Carlos. "El soneto de Cervantes 'A la entrada del Duque de Medina en Cádiz’: Análisis y anotación filológica." Cervantes y Andalucía: Biografía, escritura y recepción: Actas del Coloquio Internacional, Estepa, diciembre de 1998. E. Pedro Ruiz Pérez. Estepa: Ayuntamiento de Estepa, 1998. I43-63.

Miekkavaara, Leena. "Unknown Europe: The Mapping of the Northern Countries by Olaus Magnus in I539." Belgeo [online version] 3-4: 2008. 22 May, 2013. Web. Accessed 28 September, 20I6. <http://belgeo.revues.org/7677>.

Pettas, William A. A Sixteenth-Century Spanish Bookstore: The Inventory of Juan de Junta. Philadelphia: American Philosophical Society, I995.

Riley, E. C. Cervantes's Theory of the Novel. Oxford: Clarendon, 1962.

Rojo Vega, Anastasio. "Manuscritos y problemas de edición en el siglo XVI," Castilla: Estudios de literatura I9 (1994): I29-I57.

—. "Sobre los Duques de Béjar y sobre Miguel de Cervantes." Internet Resource. Accessed 4 Februrary, 20I8. <www.anastasiorojo.com>.

Rueda Ramírez, Pedro. "Las estampas o ver por papel: La llegada de grabados a tierras americanas en los siglos XVI-XVII." Representaciones: Revista de Estudios sobre Representaciones en Arte, Ciencia y Filosofía 2.I (2006): 35-58.

Sacchetti, Maria A. Cervantes' PeRsiles y SigISMUNDA: A Study of Genre. Woodbridge: Tamesis, 200I.

Saxo, Grammaticus, Karsten Friis-Jensen, and Peter Fisher. Gesta Danorum: The History of the Danes. Oxford: Oxford UP, 2015.

Tasso, Torquato. I Dialoghi di Torquato Tasso. Ed. Cesare Guasti. 2 Vols. Florence: Felice Le Monnier, I858.

-. Il Mondo Creato. Ed. Benedetto Menzini. 2 Vols. Firenze: G. Galletti, I825.

-. Il Re Torrismondo. Ed. Vercingetorige Martignone. Parma: Fondazione Pietro Bembo, 1993.

—. King Torrismondo. Ed. Maria C. Passaro Pastore. New York: Fordham UP, 1997.

Torquemada, Antonio de, and Enrique Suárez Figaredo, Eds. "Jardín de flores curiosas." Lemir: Revista de Literatura Española Medieval y del Renacimiento I6 (2012): 605-834. Web.

- Jardin de flores curiosas. Antwerp: Juan Corderio, I575.

Universal Short Title Catalogue. Dir. Andrew Pettegree. Co-Dir. Malcolm Walsby. U of St Andrews, Scotland: USTC, 20I6. <http://ustc.ac.uk/>. Accessed 5 March 2016. Web.

Vidal y Díaz, Alejandro de. Memoria Historica de la Universidad de Salamanca: Redactada en virtud de encargo del Sr. D. Vincente Lobo, Rector. Salamanca: Oliva, I869. 
Wardropper, Bruce W. “Don Quixote: Story or History?” Modern Philology 63.I (1965): I-II.

Whitenack, Judith A. 'Don Quixote and the Romances of Chivalry Once Again: Converted Paganos and Enamoured Magas.' Cervantes I3:2 (I993): 6I-9I.

Wilson, Diana de Armas. Allegories of Love: Cervantes's Persiles AND SigISMUNDA. Princeton: Princeton UP, I99I. 